\title{
COMPARISONS OF OGIVE SYSTEMS UNDER VARIOUS REGIMES
}

\author{
By David Atherton \\ (Toronto, Canada)
}

\begin{abstract}
It is suggested that the dark and light bands associated with a wave ogive system are the result of preferential adsorption of wind-blown dust by interstitial water held in narrow coarsely crystalline bands, which are more frequent in the dark bands. These narrow bands are presumed to be produced by regelation on the closure of extensive crevasses in the cwm zone above the ice fall and that, although originally uniformly distributed, there is a bunching effect caused by velocity fluctuations in the glacier at the top of the ice fall. These velocity fluctuations, which are attenuated by irregularities in the glacier's bed, produce waves at these points, multiple irregularities producing multiple wave systems.
\end{abstract}

RÉsumÉ. On suggère que les bandes sombres et claires associées avec un système d'onde en ogive sont le résultat d'une adsorption préférentielle de la poussière transportée par le vent par l'eau intersticielle contenue dans les bandes étroites à gros cristaux qui sont plus fréquentes dans les bandes sombres. On pense que ces bandes étroites sont produites par regel à la fermeture des crevasses importantes dans la zone de "corrie" au-dessus de la chute de glace et que, bien qu'elles soient à l'origine uniformément réparties, il y a un effet de groupement causé par les variations de vitesse dans le glacier au sommet de la chute de glace. Cies variations de vitesse, qui sont atténuées par les irrégularites du lit du glacier, produisent des ondes en ces points, les nombreuses irrégularités engendrant de nombreux systèmes d'onde.

Zusammenfassung. Man kann annehmen, dass die dunklen und hellen Bänder eines Ogiven-Systems das Ergebnis der selektiven Adsorption von windverwehtem Staub durch Wasser in den Fugen von schmalen, grosskristallinen Bändern sind, die am häufigsten in den dunklen Bändern anzutreffen sind. Diese schmalen Bänder werden vermutlich durch Gefriervorgänge beim Schliessen grosser Spalten in der Kar-Zone über dem Gletscherbruch gebildet. Ihre ursprünglich regelmässige Verteilung wird durch Druckwirkungen, die sich durch Geschwindigkeitsänderungen im Gletscher am oberen Rand des Eisfalles einstellen, zusammengepresst. Solche Geschwindigkeitsänderungen, die durch Unregelmässigkeiten im Gletscherbett abgeschwächt werden, erzeugen Wellen an diesen Punkten, wobei vielfältige Unregelmässigkeiten auch vielfältige Wellensysteme zur Folge haben.

\section{INTRODUCTION}

This paper has been stimulated by the descriptions of ogive systems given by King and Lewis ( 1961 ) and by Fisher ( 1962 ); however these papers treat only temperate alpine glaciers. The author has participitated in detailed research on ogive systems in Iceland and Greenland and has also examined them in Alaska. These three regions have different climatic conditions and the characteristics of the ogive systems formed under the various regimes are somewhat different. This paper describes briefly some of the features of the ogive systems observed; it compares their typical characteristics and attempts to correlate them in order to consider theories for the formation of bands and waves.

\section{Iceland (Cambridge South-East Iceland Expedition, I957)}

An intensive study was made of the ogive system on Svinafellsjökull, an outlet glacier from the ice cap Vatnajökull, and some neighbouring glaciers showing ogives were also examined (Elliston, I957). Svinafellsjökull appears to be very similar to the temperate alpine type of glaciers of Norway so well described by Lewis and others. Its ice fall has a drop of about $500 \mathrm{~m}$. and its surface gradient is nearly 35 degrees. It is I $\mathrm{km}$. wide at the ice fall and the firn line is approximately mid-way up the ice fall at $\mathrm{r}, 050 \mathrm{~m}$.

The waves are not immediately discernible being only a few meters in amplitude; in fact, considering the vigorous ice fall, they are small even compared with other alpine glaciers. There are annual waves and bands, some of them multiple. The wave-length agrees with the annual movement, within the accuracy of observational extrapolation, and decreases on descending the glacier from a maximum wave-length of about $200 \mathrm{~m}$. at the foot of the ice fall. We found it easier to distinguish the dark bands later in the summer, though even then they were not striking. However, much of the local rock is of volcanic origin and produces 
coarse particles on weathering that are not easily transported by wind; also this part of Iceland is notoriously wet. Both of these factors reduce the amount of local wind-blown dust and this probably explains why the bands are not darker. We were able to locate the dark bands as being on the forward or down-glacier crests of the waves, as shown schematically in Figure 1. This is the opposite of the relationship suggested by Nye and Lewis for the Odinsbre ogive system on Austerdalsbreen (King and Lewis, I96 I, p. 935). Indeed, if their observation is correct, I think that it may be something unusual since all the ogive systems I have investigated have had the dark bands on the lower edges of the waves. There is a great deal of avalanching on the ice fall in the summer and this is probably a significant contribution to the glacier's movement.

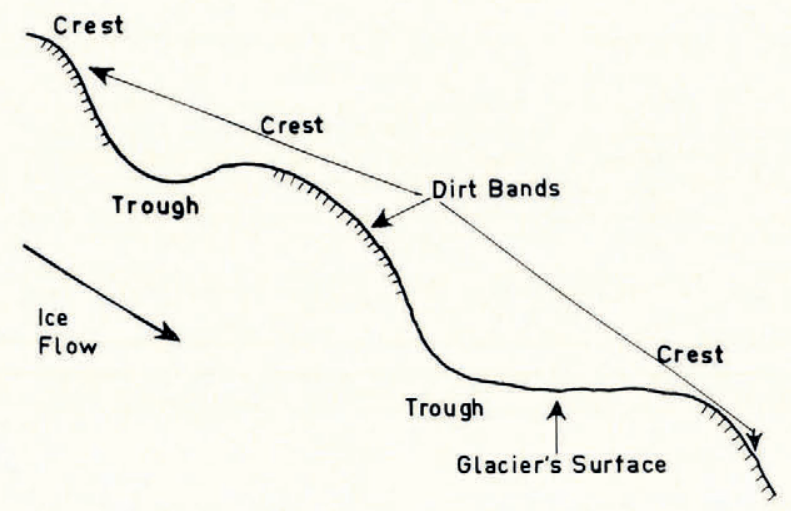

Fï. I. Typical profile of wave ogives showing positions of dark bands relative to waves

Greenland (Cambridge West Greenland Glaciological Expedition, r958)

A detailed study was made of the wave ogives and bands on the glacier Lyngbræ, an outflow from the Sukkertoppen ice cap. Observations of the eastern fork of the glacier Vimmelskaftet were also made. The main scientific reports of the expedition are not yet completed.

The waves were typically of large amplitude and were formed on the lower parts of the ice falls rather than beneath them. Dark bands were located on the down-glacier sides of the waves.

The main Lyngbræ ice fall is about $400 \mathrm{~m}$. high and $0.8 \mathrm{~km}$. across. Its gradient averages about 35 degrees on the upper part of the ice fall and the firn line is a little above the top of the ice fall. There is very little avalanching on the ice fall. The wave system starts mid-way up the ice fall. The waves themselves are very pronounced; in some cases the leading edges of the waves are nearly vertical $20 \mathrm{~m}$. cliffs. The uppermost waves in any system are always hard to distinguish, but we could discern here that the highest waves were in fact multiple waves which later coalesced to form single waves as the glacier descended the ice fall. The wavelength at the bottom of the ice fall was compatible with the extrapolated annual movement at that point of about $100 \mathrm{~m}$. The dark bands were very distinct on the down-glacier slopes of the waves, and the bands continued to be visible right down to the glacier's terminus, over a hundred in all. They became very much darker during the season; indeed it was noticeable on a photographic exposure meter that, whereas in mid July, the difference between readings on dark and light bands was half a stop, by late August, this contrast had increased to more than two stops. The very large increase in the amount of surface dirt was attributed primarily to the unusually large amount of wind-blown dust produced by the frequent rock falls resulting from severe frost shatter, rather than dirt contained in the ice being exposed by 
ablation. On one occasion a particularly large rock fall produced a cloud of rock flour over half a kilometer long.

A careful inspection was made of the complex wave system found on the ice fall of the eastern fork of Vimmelskaftet, since it was considered that this evidence would be very useful for testing many theories of wave formation. This ice fall, which descends about $300 \mathrm{~m}$., is $0.5 \mathrm{~km}$. wide and the average gradient is 33 degrees. The firn line is about $100 \mathrm{~m}$. above the top of the ice fall, and there is not much avalanching on the ice fall though there are big seracs. Figure 2 is a sketch map of the main features of the ice fall and shows, looking upglacier from beneath the ice fall, a small valley running down the lower part of the ice fall just left (east) of centre (see also Figure 3). To the right, after working out the sequence of the

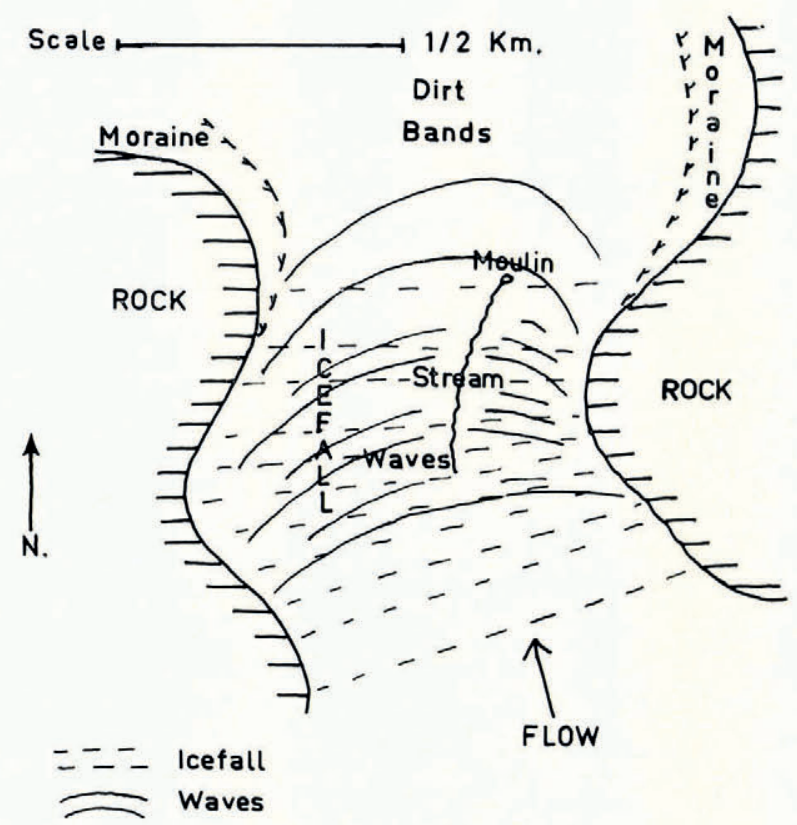

Fig. 2. Sketch map of eastern fork of Vimmelskaftet, Greenland, showing the main features of the ice fall and the ogive system

waves, whose wave-length decreases as the glacier descends, it is clear that about a third of the way up the ice fall two waves are formed each year, a major wave and a subsidiary, slightly smaller wave beneath it; as the glacier descends the sequence of waves clearly shows that the subsidiary wave is gradually merged with the leading edge of the major wave. The process is complete after descending about eight years (or major waves). To the left of the valley the multiplicity of waves is even more complex. Major waves may be distinguished, and these appear to be related to major waves on the right-hand side of the valley; however some of these major waves have one subsidiary small wave beneath them and some have two discernible. The alternation between one or two subsidiary waves appears to be random. Again the major wave coalesces with its subsidiaries. Where the central valley ends with its stream entering a moulin (at about the $5^{\text {th }}$ wave) the major waves become continuous right across the glacier, this remains true as far down the glacier as the waves are visible (some twenty to thirty waves). The dark bands are easily visible on this glacier and are located on the forward or down-glacier slopes of both major and subsidiary waves and continue a long way down the glacier from the wave system. 


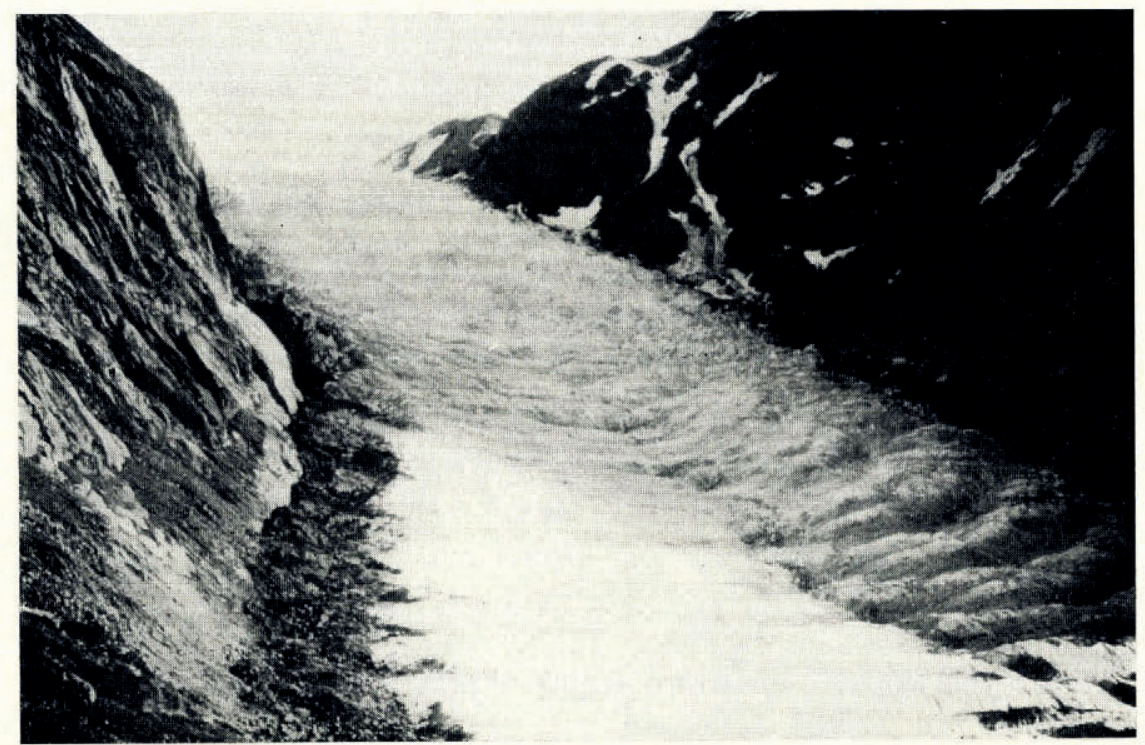

Fig. 3. Eastern fork of Vimmelskaftet, Greenland. This ice fall has a complex system of wave ogives. To the right of the valley a double wave is formed each year which coalesces lower down the system into a single annual wave; to the left an irregular number of waves (two or three) are formed each year and later coalesce to form a wave continuous across the valley. Note the dirt bands on the forward edges of the waves

Alaska (Milton Mt. McKinley Range Expedition, i960)

A brief study was made of a wave ogive system at 2, $150 \mathrm{~m}$. on the south side of the north fork of the Eldridge Glacier (see Fig. 4). A description of the region has been given (Carter

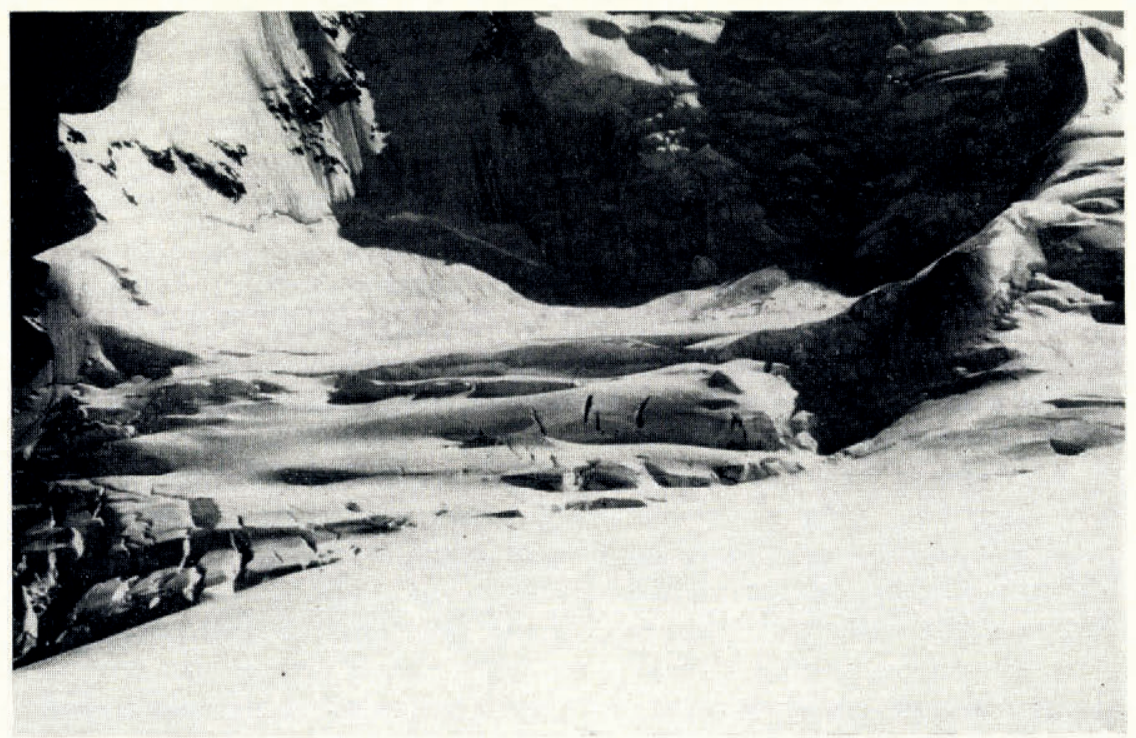

Fig. 4. Wave system on the north fork of the Eldridge Glacier, Alaska. The system ends at about 2,I5o m. a.s.l. and the firn line on this glacier is at about $1,800 \mathrm{~m}$. a.s.l., so that the whole system is well above the firn line. Note the avalanching into the cwm and also that the waves start at the top of the ice fall 
and Atherton, I96r). The waves are formed on a small ice fall of about I50 m. drop and a gradient of 20 degrees on a tributary glacier emerging from a cwm to the south. There is considerable avalanching into this cwm as shown in the photograph (Fig. 4). There are four waves which appear to be annual. Figure 5 is a sketch map of the profile.

The system is unusual in that it is entirely above the firn line and that, in this region, the main accumulation period is during the late summer. Nye's theory of summer ablation (Nye, 1958) acting on a thin fast-moving ice fall, reducing the amount of ice descending during the summer compared with the snow-blanketed winter ice which follows, forming a wave, cannot be inverted to explain such waves. The highest wave is near the top of the ice fall, so that it takes several seasons for the ice to move down the ice fall, therefore there cannot be a separation into ice descending during the winter and ice descending during the summer as required by such a theory. The wave-lengths increase going higher, as on an ice fall below the

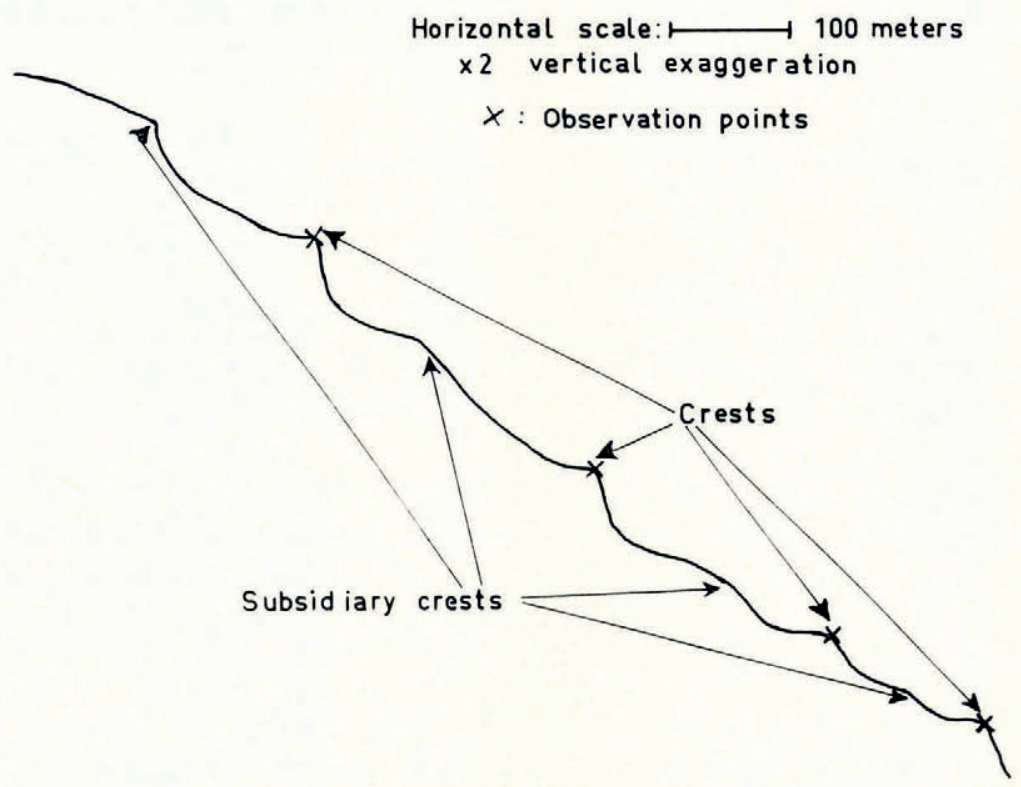

Fig. 5. Profile of the wave system on a tributary glacier entering the north fork of the Eldridge Glacier from the south at an elevation of approximately $2,150 \mathrm{~m}$. (just below the lowest crest shown). The observations were made using a range-finder and an inclinometer

firn line, although, since it is an accumulation zone, they might have been expected to decrease in this case. This indicates that this tributary glacier thickens towards the bottom of the ice fall.

The leading or down-glacier edges of some of these waves have areas of dirt which are visible after periods of ablation without precipitation, however these areas are probably caused by greater ablation and less accumulation on the wave fronts than in the troughs, which exposes dirt layers in the firn.

\section{The Relationship Between Dark Bands and Waves}

Dark bands occur normally on the down-glacier slopes of the waves. They never occur above the wave system but appear first on or near the wave system and may extend down glacier right to the terminus.

The evidence from the eastern fork of Vimmelskaftet is especially significant in that a complex system of multiple waves has a dark band on the down-glacier crest of each wave; 
this demonstrates that there is a relationship between the waves and the dark bands and that it is not merely the coincidence of two annual formations. This implies that the waves and the dark bands both result from the same process.

\section{Theories of Band Formation}

The typical darkening of the dark bands beneath a wave ogive system, occurring during the summer season, indicates that the glacier surface is washed almost clean of dirt by the spring melt and that the dirt visible later in the season is mostly collected during that year. King and Lewis ( $196 \mathrm{r}$ ) also reported this and attributed it to more dirt being brought to the surface of the dark bands by summer ablation. If this were the main effect, it would seem that, contrary to observation, the bands observed in Iceland should be darker than the ones investigated in Greenland, because the Greenlandic glaciers are on the edge of an extensive

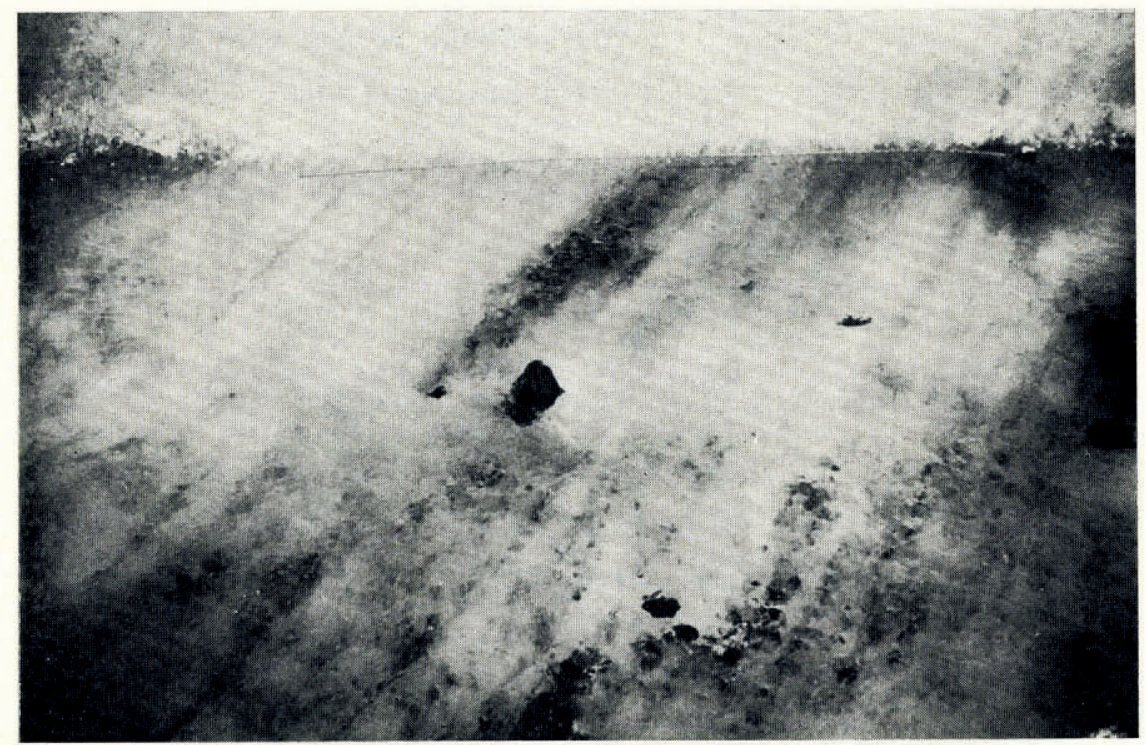

Fig. 6. Fine bands of coarse crystals marked out in a stream bed by the trapped dirt. These are in the dark part of an ogive on Lyngbre, Greenland. The rule is extended $I \mathrm{~m}$.

ice sheet with little exposed land to provide sources of dirt for the predominantly catabatic continental wind system, so that the atmosphere contains little dust to be collected by precipitation; therefore the amount of dirt contained within the ice should be small. On the other hand, in Iceland the ice cap is much smaller, so that it cannot generate its own wind system to the same extent, and winds from inland may collect dust from the lava plateaux which will be trapped by precipitation as the wind blows across an ice cap; it would therefore be expected that this ice would contain considerably more dirt; also, since the rate of ablation is higher, it would be expected that the dirt bands should be the more pronounced.

I would suggest that the dominant mechanism is the preferential adsorption of locally generated wind-blown dust (as opposed to the continental effects of wind-blown dust considered in the previous paragraph) and that the bands in Greenland were darker because there were considerable sources of dust beside the glaciers in question. This suggestion removes another difficulty of the ablation theory, namely that the dark bands usually start some distance below the wave ogives although the crystalline structure of the bands considered later is plainly visible in the wave ogives, so that ablation would be expected to 
expose some dirt banding in the wave system since it has been noted that most of the dirt in a dark band has been collected during a single season. However, preferential adsorption of wind-blown dust would only be effective further down the glacier, since the dust-forming rock outcrops are typically beside the lower part of the ice fall and the catabatic wind will drift the dust down-glacier from there, with the result that it will be adsorbed below the wave system itself.

King and Lewis ( $196 \mathrm{I}$ ) give a good description of typical dark bands as consisting of fine bands of coarser ice crystals with concentrations of surface dirt. The appearance of these fine bands, exposed in a stream bed on Lyngbræ, is shown in Figure 6, while Figure 7 shows the fine bands in a similar position in one of the light parts of an ogive. Some illuminating experiments were made on these ogives.

First one of these narrow bands traversing a deeply cut stream had the top few inches of surface ice axed away so that a fresh section was exposed; no noticeable dirt was then visible.

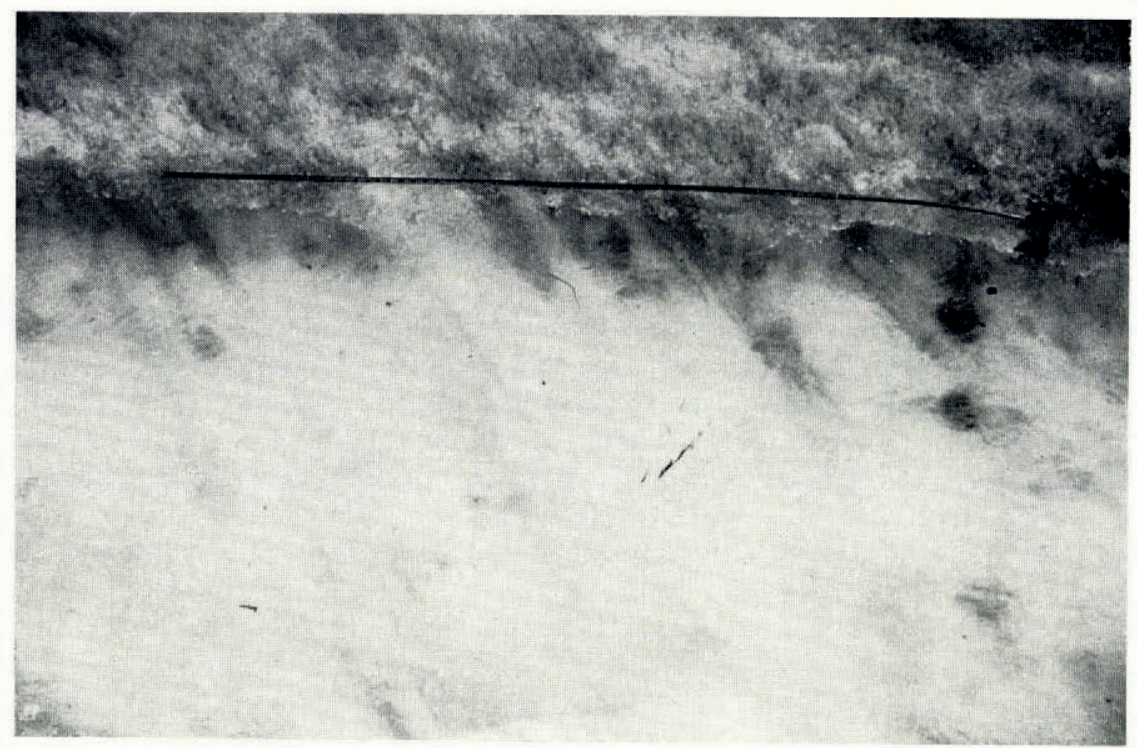

Fig. 7. Crystalline bands in a light part of the ogive. Compared with Figure 6 there are not as many bands nor such broad ones and they have not collected as much dirt because of a finer crystal structure

A small pool was then made at the top of the band and filled with purple dye. This dye percolated slowly down through the ice, but spread much more quickly through the band of coarser crystals in which it appeared to have a tendency to remain. The conclusion drawn was that the band of coarse crystals held a relatively large amount of interstitial water, trapped by capillary action, and that the dye solution diffused more rapidly through this; wind-blown dust should therefore be preferentially adsorbed by these bands. King and Lewis suggest that the trapping of dirt carried by surface water is also greater in these coarse bands, and it seems that this is also a contributing factor though not the main one.

Secondly, band counts were made. Table I summarizes the measurements made on the frequency of occurrence and relative importance of these narrow, coarsely crystalline bands in the major dark and white bands along the bed of a stream where the bands were well marked. The measurements are not easy to make, even apart from the handicap of working in a glacial stream, since the crystalline changes are not very sharply defined and also it is not practicable to select sample lengths on an entirely random basis, so that the relatively large 
standard deviations in the total percentage widths of the coarsely crystalline bands in the white and dark bands are to be expected. The conclusion that these bands are about three times as important in the dark bands as in the light ones is however valid.

These crystalline bands are characterized by their great lateral extent and their parallel arrangement both with respect to each other and with respect to the wave system. It is therefore perfectly natural to try and associate them with major crevasses on the ice fall, and King and Lewis suggest that the difference between the white and dark parts of the ogive are due to the crystalline bands being formed by the infilling of crevasses on the ice fall, which will be filled with relatively clean snow in winter and snow containing more melt water and dirt in summer; the crevasses then close and compact the infilled snow to form the band. The band counts made on Lyngbræ suggest a different reason for the contrast between the white and dark parts of the ogive; namely that it is due to relatively different proportions of coarse crystalline bands. Furthermore, since one wave is formed per year; if the crystalline bands are due to crevasses on the ice fall, the band counts show that there must be approximately one thousand major crevasses on the ice fall each year, which I believe is wrong by an order of magnitude.

I conclude that the major source of these narrow bands is in the cwm zone directly above the ice fall. My experiences have been that the frequency of crevasses in the cwm is considerably higher than on the ice fall itself and that, as the ice is moving slower in the cwm, it seems likely that a thousand crevasses could open and shut in a section corresponding to one year's movement during the time that it takes to traverse the crevassed zone at the head of the ice fall.

I consider that infilling of the crevasse with snow, or percolation of melt water is not an essential criterion for the formation of a narrow band as I believe that regelation effects produced by the pressure of closure of the crevasse would be adequate to permit the ice to sinter into larger crystals. As a crevasse opens it will form sides with slightly irregular rough surfaces. Small relative movement will ensure that, when the crevasse closes, the surfaces will no longer mate perfectly. Contact will initially be made at a few isolated points and the forces producing closure of the crevasse will generate very high local pressures which will be relieved by pressure melting. The small amounts of water thus formed will refreeze and, because of the lower surface energy of larger crystals, the refreezing will take place preferentially on the larger crystals. This complete regelation cycle of local pressure build up, presssure melting and subsequent refreezing, will occur at many points on the sides of the crevasse. Migration will occur while the crevasse closes and there will be a sintering effect. The net result will be an increase in the crystal size at the line of the crevasse.

Since a section will have crevasses opening in different places in different years as it moves across the cwm, an approximately uniform distribution of narrow bands in the glacier at the top of the ice fall would be expected; from a brief inspection of the upper part of the Lyngbræ ice fall I believe that this may be the case there. The bunching of these crystalline bands to form the broad dark and light bands associated with the wave system is, I suggest, the result of the same mechanism which forms the waves themselves.

\section{Wave Theories}

Comparing wave systems found under different regimes it would seem that, in general, the colder the glacier the greater is the amplitude of the waves. In this respect, the contrast between the Greenlandic and Icelandic glaciers was most marked. Studies of aerial and reconnaissance photographs from other regions (Alaska, Axel Heiberg Island, Norway, Switzerland) also support this conclusion.

Nye's theory of differential ablation (Nye, I958), although a plausible explanation for the Austerdalsbre wave systems, cannot be directly expanded to explain the formation of multiple wave systems with varying numbers of waves formed each year, as we observed in Greenland; 
TABle I. Band Counts on Lyngbr

Counts of numbers of narrow, coarsely crystalline bands contained in standard $40 \mathrm{in}$. ( $\mathrm{I} \cdot \mathrm{O} \mathrm{m}$.) sample length (measured along glacier flow) in major alternating dark and white band sequence.

Estimates of total width of fine bands and percentage of sample.

Count I

Exposures in stream approximately $\mathrm{I} \cdot 5 \mathrm{~km}$. from glacier's terminus.

$\begin{array}{lcrc}\text { Band } & \begin{array}{c}\text { Number of } \\ \text { fine bands }\end{array} & \begin{array}{c}\text { Total width } \\ \text { in. }\end{array} & \text { Percentage } \\ \text { White } & 4 & 7 & 18 \\ \text { Dark } & 6 & 13 & 33 \\ \text { White } & 0 & 0 & 0 \\ \text { Dark } & 14 & 18 & 45 \\ \text { White } & 5 & 6 & 15 \\ \text { Dark } & 15 & 19 & 48 \\ \text { White } & 11 & 16 & 40 \\ \text { Dark } & 13 & 18 & 46 \\ \text { White } & 7 & 5 & 13 \\ \text { Dark } & 14 & 17 & 42\end{array}$

Count 2

Exposures in stream approximately $3 \mathrm{~km}$. from glacier's terminus.

\begin{tabular}{|c|c|c|c|}
\hline Band & $\begin{array}{l}\text { Number of } \\
\text { fine bands }\end{array}$ & $\begin{array}{c}\text { Total width } \\
\text { in. }\end{array}$ & Percentage \\
\hline Dark & I I & 13 & 33 \\
\hline White & 6 & 5 & 12 \\
\hline Dark & I I & 12 & 30 \\
\hline White & 5 & 3 & 8 \\
\hline Dark & 7 & 15 & $3^{8}$ \\
\hline White & 4 & 3 & 9 \\
\hline Dark & 7 & I 2 & 30 \\
\hline White & 2 & 3 & 8 \\
\hline Dark & I I & 13 & $3^{2}$ \\
\hline White & 3 & 3 & 9 \\
\hline Dark & 10 & I I & 22 \\
\hline White & 5 & 4 & 10 \\
\hline Dark & 14 & 18 & $4^{2}$ \\
\hline White & 5 & 5 & I3 \\
\hline Dark & 16 & 19 & 47 \\
\hline White & 5 & 4 & 10 \\
\hline Dark & I I & 13 & 33 \\
\hline White & 12 & 9 & 22 \\
\hline Dark & 14 & 17 & 43 \\
\hline White & 6 & 6 & 15 \\
\hline Dark & 14 & 17 & $4^{2}$ \\
\hline White & 3 & 2 & 5 \\
\hline Dark & 10 & I 6 & 40 \\
\hline White & 7 & 6 & i5 \\
\hline
\end{tabular}

Mean percentage widths occupied by fine, coarsely crystalline bands:

White band 13 per cent \pm 8 per cent standard deviation

Dark band 38 per cent \pm 8 per cent standard deviation

nor is it a satisfactory explanation of the type of wave system found above the firn line in Alaska; further difficulties are also apparent in the consideration of wave systems which start high up on an ice fall.

Comparison of the widely different wave systems described suggests that there is not very much in common and that the details of the mechanisms of their formations may vary; however there are some common features.

First, ice falls are typically relatively fast moving and the glacier's thickness is generally considerably reduced so that any unevennesses in the rock bed, such as rock steps, will cause relatively large variations in the glacier's thickness. 
Secondly, I would suggest that there is a seasonal fluctuation in the mass flow of ice on a wave-forming ice fall. This could be caused by differential ablation, as in Nye's theory, in the case of many temperate alpine type glaciers, which would therefore have approximately constant velocity but seasonal fluctuations in glacier thickness; or alternatively, the varying mass flow could be caused by seasonal fluctuations in the glacier's velocity at or near the top of the ice fall; small velocity fluctuations have been observed by Elliston (1962) on temperate glaciers. This latter process would seem likely to be the wave-forming mechanism for the system described on the Eldridge glacier, where the summer accumulation pattern, accentuated by the very large number of avalanches entering the cwm during the summer (as shown in Figure 4), means that there is a considerable increase in the amount of ice in the cwm at this time, which will cause a seasonal increase in the rate of outflow.

Seasonal fluctuations of mass flow might be reasonably expected on ice falls where there is much avalanching, as on Svinafellsjökull; but on Lyngbræ there was little avalanching and less ablation than on Svinafellsjökull so that the relative ablation should be less, unless the glacier should prove to be much thinner. Since the waves had a much greater amplitude on Lyngbræ this must presumably be a velocity fluctuation effect. We measured the summer velocity on Lyngbræ directly beneath the ice fall, and this agreed well with the annual movement inferred from the wave-length of the wave ogives at this point; however, this is no evidence against the velocity fluctuation theory since the theory refers to fluctuations at the top of the ice fall, or at least to fluctuations at some point above the wave system.

Unfortunately it is obviously very difficult to measure a glacier's velocity near the top of an ice fall; photogrammetric methods are not very suitable and the scarcity of possible triangulation points, let alone the mountaineering access problem, makes survey difficult. Evidence for large seasonal velocity fluctuations is therefore scant, in fact the main reason for suggesting it is that it is very difficult to understand how a complex, multiple wave system, as found on the eastern fork of Vimmelskaftet, could be formed without such a process.

If such a fluctuation of velocity at the top of the ice fall is assumed, and there exists a system of multiple steps on the rock floor of the glacier, a system of multiple waves is understandable; furthermore, if the rock steps are not continuous across the valley, we would expect discontinuities in the wave system as observed on Vimmelskaftet. In addition, if the seasonal fluctuations are of varying magnitudes, it is possible to conceive that, with a mild fluctuation, not all the rock steps will produce waves, whereas, for a bigger fluctuation, more waves will be formed.

Velocity fluctuations at the top of an ice fall which are smoothed out to a more uniform velocity at the bottom of the ice fall, would cause a bunching effect of the postulated uniformly distributed narrow crystalline bands, originating from the cwm zone, which produce the dark and light bands.

A further observation supporting this theory is that, on Lyngbræ, we observed the formation of multiple waves, and the annual complement appeared to be formed concurrently, not sequentially as would be anticipated from the ablation modulation theory.

The coalescing of multiple waves may be explicable if a wave crest corresponds to a minimum of compressive strain and a wave trough to a maximum; consideration of a major wave with a subsidiary wave beneath it suggest that there will be a very big compression in the trough between the two tending to make them coalesce with the subsidiary being merged into the leading edge of the major wave.

To summarize, it is considered that waves are formed by seasonal fluctuations in the mass of ice flowing over rock steps on the bed of a relatively shallow part of a glacier. The fluctuations are produced by variations of glacier thickness, such as may be caused by alternation between ablation and precipitation, or by variation of the glacier's velocity above the waveforming step. The latter mechanism is considered to be normally of greatest importance since it also produces the bunching of the narrow coarse crystalline bands which form the dark 
bands associated with the wave ogives. The dark bands are formed by preferential adsorption of wind-blown dust by the coarse crystalline bands.

\section{Acknowledgement}

I owe a lot to the ideas and criticisms of many friends and our liscussions during the field-work and later; however my opinions expressed in this paper are not to be considered as a final interpretation of the results of any specific expedition. I also gratefully acknowledge support from the Royal Geographic Society, the Scott Polar Research Institute, the Worts Fund of the University of Cambridge, Clare College, Cambridge, the Mount Everest Foundation, the American Alpine Club, and many other helpers.

MS. received 24 July 1962 and in revised form 22 November 1962.

\section{REFERENCES}

Carter, A., and Atherton, D. L. 196r. Milton Mt. McKinley Range Expedition, 1960. .7ournal of Glaciology, Vol. 3, No. 3o, p. 1123-32.

Elliston, G. R. 1957. A study of the ogives on some of the outlet glaciers of Öræfajökull. Jökull, Ár 7, p. $26-32$. Elliston, G. R. 1962. Seasonal changes of speed in temperate valley glaciers. Journal of Glaciology, Vol. 4, No. 33, p. 289. [Abstract.]

Fisher, J. E. 1962. Ogives of the Forbes type on alpine glaciers and a study of their origins. Fournal of Glaciolegy, Vol. 4 , No. 31, p. 53-6r.

King, C. A. M., and Lewis, W. V. 1961. A tentative theory of ogive formation. Fournal of Glaciology, Vol. 3, No. 29, p. $912-39$.

Nye, J. F. 1958. A theory of wave formation in glaciers (Cambridge Austerdalsbre Expedition). Union Géodésique et Géophysique Internationale. Association Internationale d'Hydrologie Scientifique. Symposium de Chamonix, $16-24$ sept. $195^{3}$, p. ${ }^{1} 39^{-5}$. 